\section{NEW RECORD OF A HEADSHIELD SLUG PHANEROPHTHALMUS SMARAGDINUS (GASTROPODA: OPISTHOBRANCHIA) FROM ANDAMAN ISLANDS, INDIA}

\author{
Sumantha Narayana ${ }^{1} \&$ Raju Mohanraju ${ }^{2}$ \\ 1,2 Department of Ocean Studies and Marine Biology, Pondicherry University, \\ Brookshabad Campus, Port Blair, Andaman and Nicobar Islands 744112, India \\ ${ }^{1}$ sumantha.narayana@gmail.com (corresponding author), \\ 2 mohanrajupu@yahoo.com
}

Opisthobranchia, a subclass of gastropods, differ from their relatives Prosobranchia by the presence of a thin, reduced or absent shell, and are purely marine animals. The term opisthobranch means "back or rear gills", which is a feature specific to these groups of animals. They are hermaphroditic animals. Opisthobranchs are small and often cryptic individuals that inhabit mostly sub-tidal regions and have a low numeric density making their study difficult. Studies on opisthobranchs in India are sparse and patchy, and have only recently gained much attention from researchers. Recent works on Indian Opisthobranchia are by Apte (2009), Apte \& Salahuddin (2010), Apte et al. (2010), Matwal \& Joshi (2011), Sankar et al. (2011), and Bhave \& Apte (2011), who have studied the opisthobranchs off Lakshadweep Islands and Tamil Nadu, Gujarat and Maharashtra coasts.

Studies on the opisthiobranchs of Andaman and Nicobar Islands have been reported by Raghunathan et al. (2010), Ramakrishna et al. (2010), Sreeraj et al. (2010, (2012 a,b) and Dhivya et al. (2012).

The genus Phanerophthalmus belongs to Cephalaspida, an opisthobranch clade most closely aligned with the shelled prosobranchs. These headshield slugs are most primitive and one of the least modified form of gastropods, and exhibit great morphological diversity (Behrens et al. 2005). Phanerophthalmus species are long, cylindrical animals with very small headshield.

The current article reports a new record of an opisthobranch, Phanerophthalmus smaragdinus (Rüppell \& Leuckart, 1828) from Andamans, India.

Materials and Methods: Sample was collected from intertidal region of Burmanallah, South Andaman, during low tide when most of the area was partially submerged. The animal was brought to the laboratory for further examination and identification. Identification based on morphological characters was carried out following Gosliner et al. (2008) and C.R. Sreeraj (pers. comm. 14 July 2012). Morphology of the live specimen was studied using a stereo-zoom microscope (Leica M205a). The specimen was narcotized using few drops of magnesium chloride solution $(72 \mathrm{~g} / \mathrm{L})$, and transferred into $5 \%$ formaldehyde solution. The formaldehyde fixed animal was later transferred to $95 \%$ ethanol for long time preservation.

A specimen of the animal has been deposited in the National Zoological Collections of Zoological Survey of India, Andaman and Nicobar Regional Centre, for reference; registration number ZSI/ANRC-7619.

Results: The specimen has been identified as Phanerophthalmus smaragdinus (Rüppell \& Leuckart, 1828) which is the first record of this species from the Andaman Islands. These organisms are known from the western Indian Ocean of South Africa, Madagascar and the Seychells and Lakshadweep Islands (India) to the western Pacific of New Caledonia, Papua New Guinea, Vanuatu, Indonesia, Reunion Island, Philippines, Japan, Guam, Palau. The systematic account of the species

DOI: http://dx.doi.org/10.11609/JoTT.o3357.4113-4 | ZooBank: urn:Isid:zoobank.org:pub:4F81286E-11FF-4C0F-A287-E689A4631F82

Editor: Deepak Apte, Bombay Natural Hisotry Society, Mumbai, India.

Date of publication: 26 April 2013 (online \& print)

Manuscript details: Ms \# 03357 | Received 21 September 2012 | Final received 21 February 2013 | Finally accepted 16 March 2013

Citation: Narayana, S. \& R. Mohanraju (2013). New record of a headshield slug Phanerophthalmus smaragdinus (Gastropoda: Opisthobranchia) from Andaman Islands, India. Journal of Threatened Taxa 5(7): 4113-4114; http://dx.doi.org/10.11609/JoTT.03357.4113-4

Copyright: (C) Narayana \& Mohanraju 2013. Creative Commons Attribution 3.0 Unported License. JoTT allows unrestricted use of this article in any medium, reproduction and distribution by providing adequate credit to the authors and the source of publication.

Funding: None.

Competing Interest: None.

Acknowledgements: The authors are thankful to the Officer In-charge, Zoological Survey of India, Andaman and Nicobar Regional Centre for permitting to use the lab facilities. Special thanks to C.R. Sreeraj for his help in identification of the species and discussion during writing of the article. 
is given below. The taxonomic hierarchy of Bouchet \& Rocroi (2005) is followed.

\section{Systematics}

Informal Group: Opisthobranchia

Clade: Cephalaspidea P. Fischer, 1883

Superfamily: Haminoeoidea Pilsbury, 1895

Family: Smaragdinellidae Thiele, 1925

Genus: Phanerophthalmus A. Adams, 1850

Phanerophthalmus smaragdinus (Rüppell \& Leuckart, 1828)

Material examined: ZSI/ANRC-7619, 12.vii.2012, adult hermaphrodite, $11^{0} 34.274^{\prime} \mathrm{N} \& 92^{\circ} 44.212^{\prime} \mathrm{E}, 0.1 \mathrm{~m}$, Burmanallah, South Andaman, Andaman and Nicobar Islands, India, coll. Sumantha Narayana.

Description: The animal was long and cylindrical with a very small headshield. The mantle cavity was much reduced and occupied a terminal position at the end of the body. The shell was small, flattened and enclosed by the mantle. The sides of the foot extended into large parapodia which folded over and enclosed the body (Rudman 1972). The uniform light greenish colour of this species is distinctive (Image 1). It was found in the intertidal area, crawling through beds of algae over rocks and dead corals. The morphometric data of the specimen is shown in Table 1.

\section{REFERENCES}

Apte, D. (2009). Opisthobranch fauna of Lakshadweep Islands, India with 52 new records to Lakshadweep and 40 new records to India. Journal of the Bombay Natural History Society 106(2): 162-175.

Apte, D. \& V.K. Salahuddin (2010). Record of Hexabranchus sanguineus (Rüppell \& Leuckart 1828) from Lakshadweep Archipelago, India. Journal of the Bombay Natural History Society 107(3): 261-262.

Apte, D., V. Bhave \& D. Parasharya (2010). An annotated and illustrated checklist of the opisthobranch fauna of Gulf of Kutch, Gujarat, India with 21 new records for Gujarat and 13 new records for India: part 1. Journal of the Bombay Natural History Society 107(1): 14-23.

Behrens, D.W., C. Petrinos \& C. Schrurs (2005). Nudibranch Behaviour. New World Publications, Inc. Florida. 176pp.

Bhave, V.J. \& D.A. Apte (2011). Opisthobranch fauna of Ratnagiri, Maharashtra, India with 8 new records to India. Journal of the Bombay Natural History Society 108(3): 172-182.

Bouchet, P. \& J.P. Rocroi (2005). Classification and nomenclator of gastropod families. Malacology 47: 1-397

Dhivya, P., V. Sachithanandam \& P.M. Mohan (2012). New records on the opisthobranch fauna of the Andaman Islands, India. Indian Journal of Geo Marine Sciences 41(3): 215-217.

Gosliner, T.M., D.W. Behrens \& A. Valdes (2008). Indo Pacific Nudibranchs and Sea Slugs. Sea Challengers, 425pp.

Matwal, M. \& D. Joshi (2011). Record of Phyllidiella zeylanica (Mollusca: Gastropoda: Opisthobranchia) after 42 years from Gujarat, India. Journal of Threatened Taxa 3(7): 1951-1954; http:// dx.doi.org/10.11609/JoTT.o2769.1951-4

Raghunathan C., Sivaperuman C. \& Ramakrishna (2010). An account of newly recorded five species of Nudibranch (Opisthobranchia, Gastropoda) in Andaman and Nicobar Islands, pp. 283-288. In:

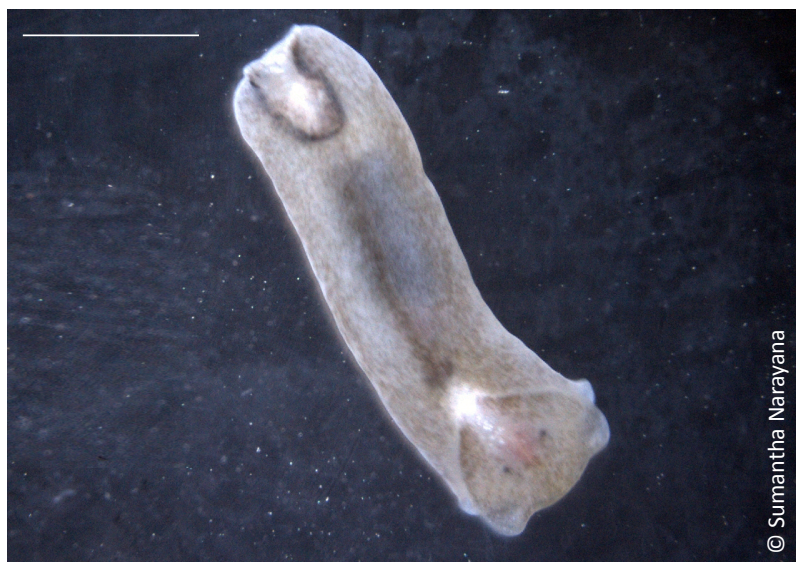

Image 1. Phanerophthalmus smaragdinus (Rüppell \& Leuckart, 1828). Scale bar: $2 \mathrm{~mm}$.

Table 1. Morphometric analysis data

\begin{tabular}{|l|c|}
\hline Body part & Measurements $(\mathrm{mm})$ \\
\hline Total crawling length & 6.232 \\
\hline Maximum width & 1.630 \\
\hline Head length & 1.539 \\
\hline Head width & 1.765 \\
\hline Tail length & 1.284 \\
\hline Tail width & 0.672 \\
\hline Eyespot diameter & 0.075 \\
\hline Distance between two eyespots & 0.546 \\
\hline
\end{tabular}

Recent Trends in Biodiversity of Andaman and Nicobar Islands. Zoological Survey of India, Kolkata.

Ramakrishna, C.R., C. Sreeraj, C. Raghunathan, J.S. Sivaperuman, R.Y. Kumar, Raghuraman, T. Immanuel \& P.T. Rajan (2010). Guide to Opisthobranchs of Andaman and Nicobar Islands. Zoological Survey of India, 196pp.

Rudman W.B. (1972). The herbivorous opisthobranch genera Phanerophthalmus A. Adams and Smaragdinella A. Adams. Procedings of the Malacological Society of London 40: 189-210.

Sankar, R., P. Raja \& A. Murugan (2011). Occurrence of opisthobranch mollusc Umbraculum umbraculum in Tuticorin coast, Southeast coast of India. Indian Journal of Geo Marine Sciences 40(4): 487490.

Sreeraj, C.R., C. Sivaperuman \& C. Raghunathan (2012a). Report on ten newly recorded Opisthobranchs (Opisthobranchia, Gastropoda) from Andaman and Nicobar Islands, India. International Journal of Oceanography and Marine Ecological System 1(2): 50-59; http:// dx.doi.org/10.3923/ijomes.2012.50.59

Sreeraj C.R., C. Sivaperuman \& C. Raghunathan (2012b). An annotated checklist of opisthobranch fauna (Gastropoda: Opisthobranchia) of the Nicobar Islands, India. Journal of Threatened Taxa 4(4): 24992509; http://dx.doi.org/10.11609/JoTT.o2783.2499-509

Sreeraj, C.R., P.T. Rajan, R. Raghuraman, C. Raghunathan, R. Rajkumar, T. Immanuel \& Ramakrishna (2010). On some new records of Sea Slugs (Class: Gastropoda, Subclass: Opisthobranchia) from Andaman and Nicobar Islands, pp. 289-298. In: Recent Trends in Biodiversity of Andaman and Nicobar Islands. Zoological Survey of India, Kolkata. 